Check for updates

Cite this: RSC Adv., 2019, 9, 25303

Received 4th May 2019

Accepted 1st July 2019

DOI: 10.1039/c9ra03331a

rsc.li/rsc-advances

\section{Highly efficient recovery of ruthenium from integrated circuit (IC) manufacturing wastewater by Al reduction and cementation}

\begin{abstract}
Van-Giang Le, (D) ${ }^{a}$ Chi-Thanh Vu, ${ }^{b}$ Yu-Jen Shih ${ }^{c}$ and Yao-Hui Huang (DD *a
Ruthenium $(\mathrm{Ru})$ is a rare-earth metal, which is employed widely in metal-processing industries. This study recovered Ru from the wastewater of an IC foundry by cementation using metallic aluminum (Al) powder as the sacrificial agent. Ru ions were efficiently reduced to the metal and coagulated with the derived aluminum hydroxide flocs. Experimental parameters included the particle size of Al, molar ratio of Al to Ru, initial Ru concentration and operation temperature. The recovery rate reached $99 \%$ under these conditions: particle size Al powder $=88-128 \mu \mathrm{m}, \mathrm{Al} / \mathrm{Ru}$ molar ratio $=2.0$, initial $\mathrm{Ru}=200 \mathrm{mg} \mathrm{L}^{-1}$, temperature $=$ $338.16 \mathrm{~K}$, reaction time $=120 \mathrm{~min}$, stirring speed $=150 \mathrm{rpm}$. The cemented $\mathrm{Ru}$ over Al powder was spherical with a rough surface. Kinetic modelling suggested that the diffusion of Ru through the ash layer of $\mathrm{Al}$ powder controlled the reaction rate with an activation energy of $40.75 \mathrm{~kJ} \mathrm{~mol}^{-1}$. A brief cost analysis demonstrated that the cementation of Ru yielded a profit of $\$ 0.180$ per $0.1 \mathrm{~m}^{3}$-wastewater.
\end{abstract}

\section{Introduction}

Ruthenium (Ru) is a rare-earth metal utilized in chemical and electrical industries. $\mathrm{Ru}$ hardens the electroplating and sputtering RuPt and RuPd alloys in electrical contacts. ${ }^{1} \mathrm{Ru}$ oxide is used in thick-film chip resistors, which accounts for approximately $50 \%$ of $\mathrm{Ru}$ production. ${ }^{2}$ Besides, $\mathrm{Ru}$ is an important element in advanced high-temperature single-crystal superalloys for making jet turbine engines. $\mathrm{Ru}$ is also applied in a variety of electrochemical, ${ }^{3}$ optical, ${ }^{4}$ medical,${ }^{5}$ catalytic, ${ }^{6,7}$ and analytical chemistries. ${ }^{8}$ Therefore, the demand of $\mathrm{Ru}$ has considerably soared. The average abundance of $\mathrm{Ru}$ in the earth's crust is only about $0.001 \mathrm{ppm},{ }^{9}$ thus there is a necessity to develop Ru recovery technologies.

Ruthenium is also an unwanted by-product from spent nuclear fuel, electronic materials, and olefin metathesis. ${ }^{\mathbf{1 0 - 1 2}}$ Integrated circuit (IC) foundries or semiconductor fabrication plants require a large quantity of $\mathrm{Ru}$, especially for surface coating. The effluent of IC manufacturing contains a high concentration of $\mathrm{Ru}$ and needs to be treated before discharge. So far, the recovery of Ru from IC foundry wastewater has not yet been reported. Al cementation is simple, highly efficient and cost-effective for the recovery of metals from wastewater. ${ }^{13}$

${ }^{a}$ Department of Chemical Engineering, National Cheng Kung University, Tainan 71710, Taiwan. E-mail: yhhuang@mail.ncku.edu.tw; Fax: +886-6-2344496; Tel: +886-2757575 ext. 62636

${ }^{b}$ Civil and Environmental Engineering Department, The University of Alabama in Huntsville, Huntsville, AL 35899, USA

${ }^{c}$ Institute of Environmental Engineering, National Sun Yat-sen University, Kaohsiung 804, Taiwan
By contrast, the solvent extraction commonly used in the recovery of metals in solution may have a limiting selectivity and products with low purity. ${ }^{\mathbf{1 4}}$ Besides, the evaporation consumes more energy than cementation in dealing with the considerable quantity of dilute solution. ${ }^{15,16}$ In the $\mathrm{Al}$ cementation recovery of $\mathrm{Ru}$, metallic $\mathrm{Al}$ acts as a reducing agent. The $\mathrm{Ru}$ ions which are converted to metal are collected by the derived-Al hydroxide by sweep flocculation as described by the following equations:

$$
\begin{gathered}
\mathrm{Ru}^{3+}+3 \mathrm{e}^{-} \leftrightarrow \mathrm{Ru}, E^{0}=+0.704 \mathrm{~V} \\
\mathrm{Al}+4 \mathrm{OH}^{-} \leftrightarrow \mathrm{Al}(\mathrm{OH})_{4}{ }^{-}+3 \mathrm{e}^{-}, E^{0}=-1.659 \mathrm{~V}
\end{gathered}
$$

The net reaction can be written as:

$$
\begin{gathered}
\mathrm{Al}+4 \mathrm{OH}^{-}+\mathrm{Ru}^{3+} \rightarrow \mathrm{Al}(\mathrm{OH})_{4}^{-}+\mathrm{Ru}, \Delta E^{0}=2.363 \mathrm{~V} \\
\mathrm{Al}(\mathrm{OH})_{4}^{-} \rightarrow \mathrm{Al}(\mathrm{OH})_{3(\mathrm{~s})}+\mathrm{OH}^{-} \text {(precipitation) } \\
\mathrm{Ru}+\mathrm{Al}(\mathrm{OH})_{3(\mathrm{~s})}=\mathrm{Ru}-\mathrm{Al}(\mathrm{OH})_{3(\mathrm{~s})} \text { (coagulation) }
\end{gathered}
$$

During cementation, Ru can be deposited at cationic sites on the surface of $\mathrm{Al}$, whereas the dissolution of $\mathrm{Al}$ occurs at anionic sites. The reaction within the $\mathrm{Al} / \mathrm{Ru}$ system can be deemed irreversible since the electro-motive force between $\mathrm{Ru}^{3+}$ and $\mathrm{Al}$ is high. ${ }^{17}$ This work studied the recovery of $\mathrm{Ru}$ from wastewater using aluminum (Al) powder. The effects of particle size of $\mathrm{Al}$ powder, $\mathrm{Al} / \mathrm{Ru}$ molar ratio, initial $\mathrm{Ru}$ concentration and temperature on the removal rate of $\mathrm{Ru}$ were investigated. The operation cost was analyzed to examine the economic feasibility of $\mathrm{Ru}$ recovery. 


\section{Materials and methods}

\subsection{Chemicals}

Chemicals employed in this study include aluminum powder (purity 99.5\%, Qingdao Ocean Import and Export Co., China), sodium hydroxide (Merck KGaA, Germany) and nitric acid (SigmaAldrich, U.S.A.). A laboratory-grade RO-ultrapure water system (resistance $>18.0 \mathrm{M} \Omega$ ) was used for DI water supply. All purchased chemicals were of laboratory grade and used as received. Al powder (purity 99.5\%, from Qingdao Ocean Import and Export Co., China) was used as the sacrificial agent for $\mathrm{Ru}^{3+}$ ions removal. In order to study of the effects of different particle sizes of $\mathrm{Al}$ powder on the recovery, the powder was sieved into three fractions (as indicated in Table 1) and then employed in recovery experiments.

\subsection{Experimental procedures}

Real wastewater collected from a local IC foundry was used for experimental design. Metal composition in the effluent of $\mathrm{Ru}-$ plating process under alkaline conditions ( $\mathrm{pH}$ 8.67) includes $23.5 \mathrm{mg}$ Ru per L, $2 \mathrm{mg} \mathrm{Zn}$ per L, $1.3 \mathrm{mg}$ Fe per L, and $0.5 \mathrm{mg} \mathrm{Ni}$ per $\mathrm{L}$. The initial concentrations of $20-200 \mathrm{mg} \mathrm{L}^{-1} \mathrm{Ru}$ were spiked for cementation experiments. The low concentration of impurity (e.g. $\mathrm{Zn}, \mathrm{Fe}$ and $\mathrm{Ni}$, which even are absent from EDS analysis) in the wastewater benefits the recovery of $\mathrm{Ru}$. Base metals precipitate more easily than the noble metals and may decrease the purity of Ru. ${ }^{13}$ The effluent was spiked with standard solution (Sigma-Aldrich Co.) to make up initial certain concentrations of $\mathrm{Ru}\left(20-200 \mathrm{mg} \mathrm{L}^{-1}\right)$ for cementation experiments. Duplicate experiments were carried out in $500 \mathrm{~mL}$ volumetric flasks at $301.16 \mathrm{~K}$. The $\mathrm{pH}$ value of the solution was adjusted using $1 \mathrm{M} \mathrm{NaOH}$. During the experiment, the solutions containing the coagulating agent (Al powder) were added slowly into the Ru wastewater while stirring $(150 \mathrm{rpm})$. Effects of $\mathrm{Al} / \mathrm{Ru}$ molar ratios, particle sizes of $\mathrm{Al}$ powder, initial $\mathrm{Ru}$ concentrations and temperature on the cementation efficiency were studied (Table 1). When the chemical reaction had finished, the precipitate was allowed to settle down for $60 \mathrm{~min}$, collected and then dried under vacuum at $313.16 \mathrm{~K}$ for $24 \mathrm{~h}$. The precipitate next underwent subsequent solid characterization, while the supernatant was analyzed for residual Ru content.

\subsection{Analytical methods}

The concentration of $\mathrm{Ru}$ and other elements in the solution was determined using an inductively coupled plasma-optical

Table 1 Experimental design for cementation recovery of Ru

\begin{tabular}{ll}
\hline Parameters & Values \\
\hline $\begin{array}{l}\text { Particle sizes } \\
\text { of Al powder }\end{array}$ & $149-177 \mu \mathrm{m}\left(\right.$ surface area $0.051 \mathrm{~m}^{2} \mathrm{~g}^{-1}$, \\
& $\left.\mathrm{pH}_{\mathrm{pzc}} 9.3\right) ; 88-125 \mu \mathrm{m}($ surface area \\
& $\left.0.103 \mathrm{~m}^{2} \mathrm{~g}^{-1}, \mathrm{pH}_{\mathrm{pzc}} 9.2\right) ; 53-88 \mu \mathrm{m}$ \\
& $\left(\right.$ surface area $0.152 \mathrm{~m}^{2} \mathrm{~g}^{-1}$, \\
& $\left.\mathrm{pH}_{\mathrm{pzc}} 8.5\right)$ \\
Al/Ru molar ratios & $0.5,1.0,2.0$ \\
Initial Ru & $20,50,100,200$ \\
concentrations $\left(\mathrm{mg} \mathrm{L} \mathrm{L}^{-1}\right)$ & \\
Temperature $(\mathrm{K})$ & $308.16,318.16,328.16,338.16$
\end{tabular}

emission spectrometer (ICP-OES, ULTIMA 2000, HORIBA Ltd., Japan). Glassware and plastic sample containers for ICP analysis were soaked in $5 \% \mathrm{HNO}_{3}$ and oven-dried before use. The ICP standard solutions were purchased from High-Purity Standards (Charleston, USA). The minimum detection limit (MDL) of $0.0005 \mathrm{mg} \mathrm{Ru}$ per $\mathrm{L}$ was determined by tripling the standard deviation from the analysis of seven samples with the same concentration. The calibration curve was constructed with a correlation coefficient $\left(R^{2}\right)$ of 0.9998 . The mid-point checks and spike recoveries ranged from $0.25 \%$ to $3.60 \%$, and from $96 \%$ to $110 \%$, respectively. The morphology, surface composition and crystallographic structure of Ru precipitate was studied using the scanning electron microscope (SEM, JOEL JXA-840, HITACHI S4100), the energy dispersive spectrometer (EDS, LINKS AN10000/85S), and the X-ray diffraction (XRD, DX III, Rigaku Co., Japan), respectively.

\section{Results and discussion}

\subsection{Recovery of Ru by Al cementation}

The Al powder with different particle size range of (53-88, 88125, and 149-177 $\mu \mathrm{m}$ ) were applied to recover $\mathrm{Ru}$ in the solution as shown in (Fig. 1a). Accordingly, the cementation efficiency increases from $80.3 \%$ to $95.6 \%$ with decreasing the particle size of Al powder from 149-177 $\mu \mathrm{m}$ to $88-125 \mu \mathrm{m}$, because of the increase in the specific surface area of $\mathrm{Al}$ (Table 1). However, as the Al particle size declines to $53-88 \mu \mathrm{m}$, the efficiency drops to $77.3 \%$. The high surface area would accelerate the oxidation of fresh metallic $\mathrm{Al}$ surface sites, deteriorating the $\mathrm{Ru}$ cementation. ${ }^{17}$ Effect of molar ratio of $\mathrm{Al} / \mathrm{Ru}(0.5,1$ and 2$)$ on the recovery of $\mathrm{Ru}$ is shown in (Fig. 1b). The recovery increases substantially from $56.4 \%$ to $95.4 \%$ when the molar ratio is increased from 0.5 to 1 ; the ratio increased up to 2 slightly improves the efficiency to $98.8 \%$, which is simply attributed to the greater quantity of active surface sites produced from higher dosage of $\mathrm{Al}$ for the cementation reaction.

Fig. 1c presents the effect of initial Ru concentration (20 to $200 \mathrm{mg} \mathrm{L}^{-1}$ ) on the recovery of Ru using 88-128 $\mu \mathrm{m} \mathrm{Al}$ powder under $\mathrm{Al} / \mathrm{Ru}$ molar ratio of 2.0 . The recovery efficiency of $\mathrm{Ru}$ increases from $94.5 \%$ to $98.4 \%$ with increasing the initial $\mathrm{Ru}$ concentration from 20 to $200 \mathrm{mg} \mathrm{L}^{-1}$. The cementation rate of $\mathrm{Ru}$ was insignificantly influenced by the selected initial $\mathrm{Ru}$ concentrations. Whereas, the removal rate of $\mathrm{Ru}$ is subject to the $\mathrm{Ru}$ adsorption on to the $\mathrm{Al}$ precipitates; more $\mathrm{Ru}$ left in the solution would be in equilibrium with the adsorbed Ru species over $\mathrm{Al}$ as higher initial $\mathrm{Ru}$ level was adopted. Effect of temperature on the recovery of $\mathrm{Ru}$ are presented in (Fig. 1d). Increasing the cementation temperature increases the recovery efficiency of $\mathrm{Ru}$. Although the adsorption reaction is normally exothermic, the temperature would help breaking up the passive oxide layer over the Al particle, improving the effective contact between $\mathrm{Ru}$ and $\mathrm{Al}$. The recovery of $\mathrm{Ru}$ is maximized at $98.5 \%$ in $120 \mathrm{~min}$ at $338.16 \mathrm{~K}$. Consequently, the cementation of $\mathrm{Ru}$ from the solution (initial $[\mathrm{Ru}]=200 \mathrm{mg} \mathrm{L}^{-1}$ ) is optimized under conditions: molar ratio of $\mathrm{Al} / \mathrm{Ru}=2.0, \mathrm{Al}$ powder size $=$ 88-128 $\mu \mathrm{m}$, temperature $=338.16 \mathrm{~K}$, in $120 \mathrm{~min}$ and $150 \mathrm{rpm}$ of stirring speed. 

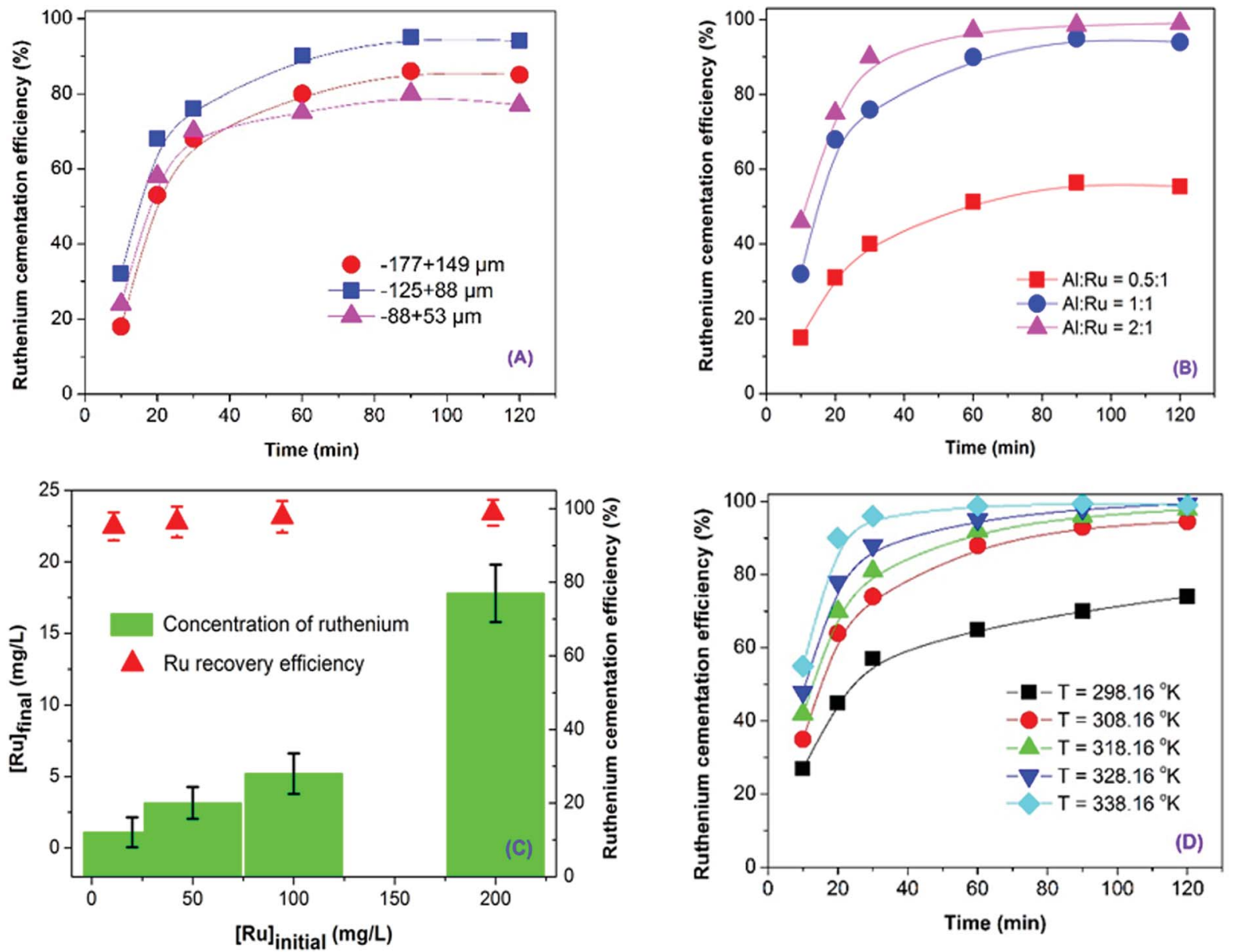

Fig. 1 Effects of (A) Al powder sizes (Al/Ru molar ratio $=1.5,[R u]=200 \mathrm{mg} \mathrm{L}^{-1}, T=308.16 \mathrm{~K}$ and $150 \mathrm{rpm}$ ), (B) Al/Ru molar ratios (Al powder size $=88-128 \mu \mathrm{m},[\mathrm{Ru}]=200 \mathrm{mg} \mathrm{L}^{-1}, T=308.16 \mathrm{~K}$ and $150 \mathrm{rpm}$ ), (C) initial Ru concentrations (Al/Ru molar ratio $=2.0$, Al powder size $=88-128 \mu \mathrm{m}$, $T=308.16 \mathrm{~K}$ and $150 \mathrm{rpm}),(\mathrm{D})$ temperature (Al/Ru molar ratio $=2.0$, Al powder size $\left.=88-128 \mu \mathrm{m},[\mathrm{Ru}]=200 \mathrm{mg} \mathrm{L^{-1 }} \mathrm{and} 150 \mathrm{rpm}\right)$ on the cementation of $\mathrm{Ru}$.

Adsorption and cementation have been employed for the recovery of Ru from wastewater (Table 2). The adsorption can achieve around $90 \%$ of Ru recovery, while the cementation shortens duration for attaining the similar rate of Ru recovery.
Kwak et al. (2013) and Ohta et al. (2002) synthesized polyethylenimine-modified bacteria, ${ }^{18}$ and alginate gel polymer, ${ }^{19}$ as adsorbents to adsorb Ru from acidic solution and achieved a 90\% recovery after 24 and 48 hours, respectively.

Table 2 Summary of recovery technologies for ruthenium

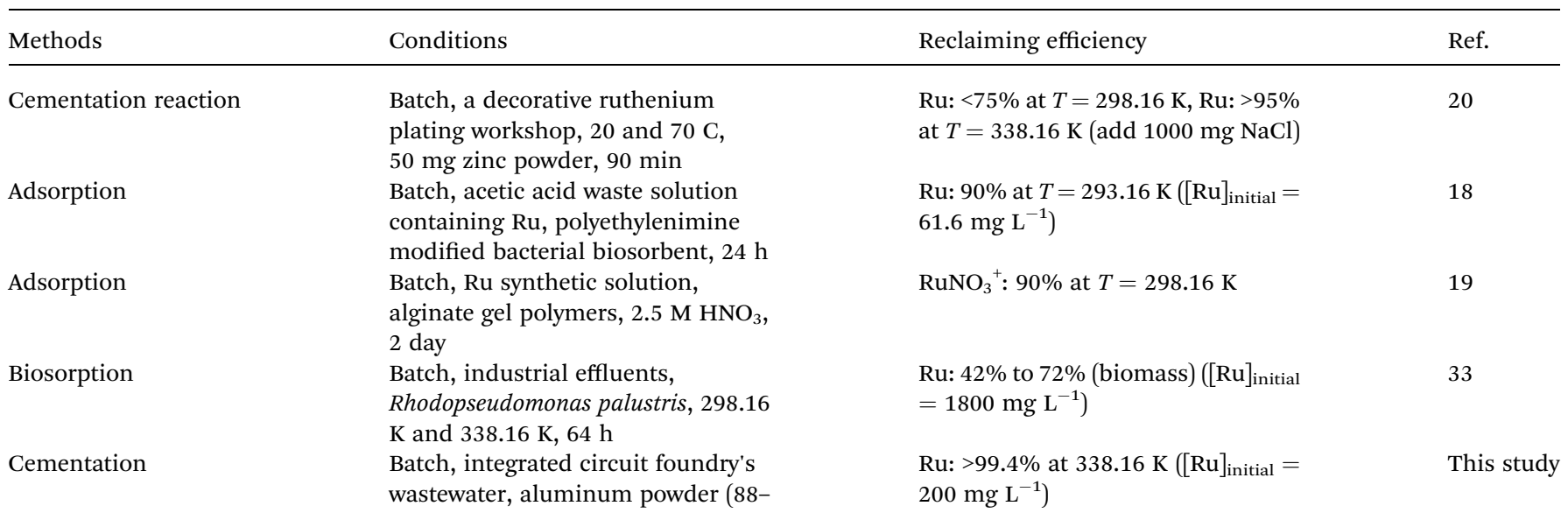



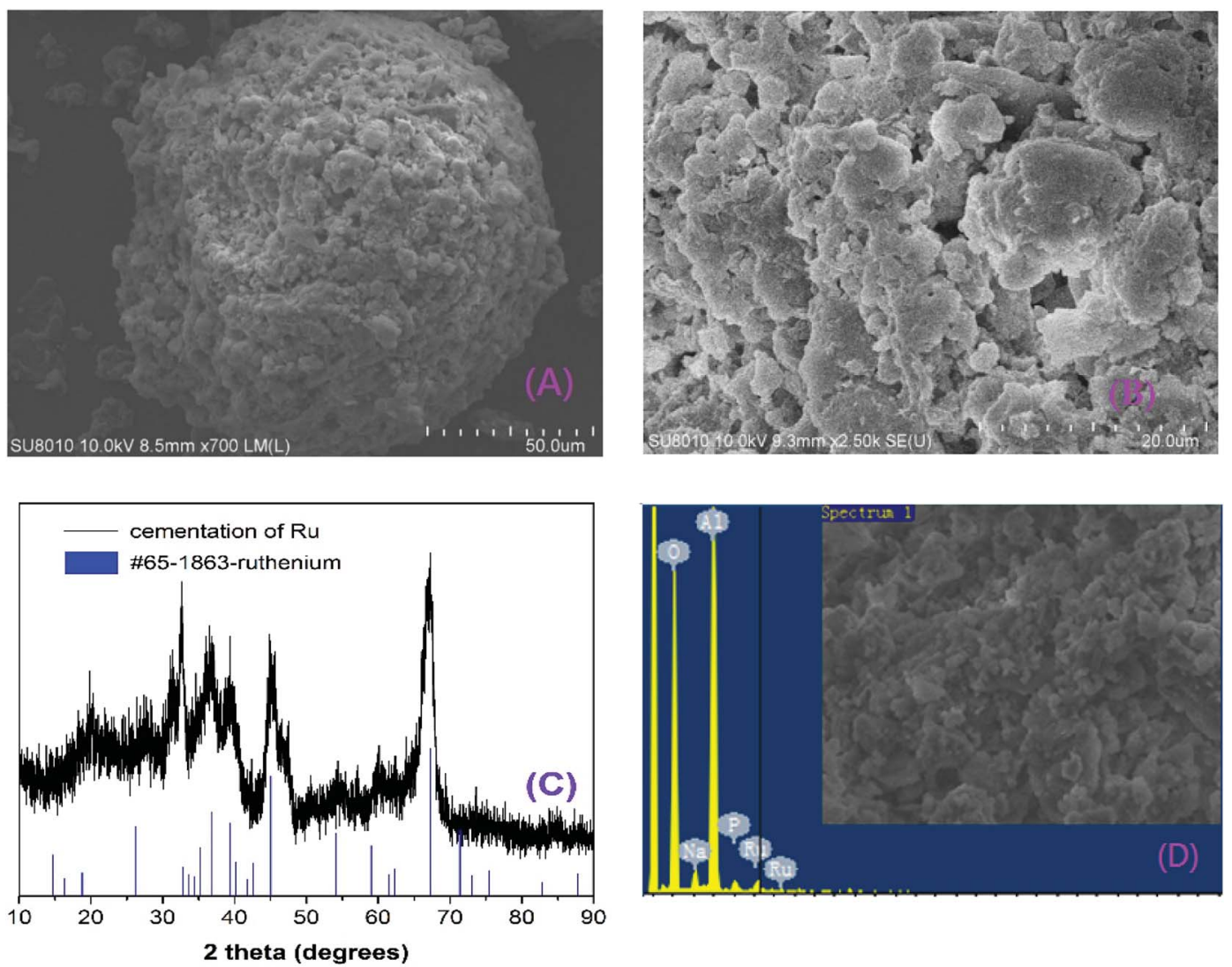

Fig. 2 Morphology of cemented Ru analyzed by SEM with magnification of $(A) \times 50$, (B) $\times 20$; (C) XRD pattern of cemented Ru; SEM and EDS spectrum of cemented Ru with magnification of (D) $\times 50$.

Aktas et al. (2018), however, utilized $\mathrm{Ru}$ cementation from electroplating wastewater and; accordingly, increasing temperature from 293.16 to $343.16 \mathrm{~K}$ improved the $\mathrm{Ru}$ recovery from $75 \%$ to $95 \%$ after 90 min. $^{20}$ In this study, with an initial Ru concentration of $200 \mathrm{mg} \mathrm{L}^{-1}$, about $99 \%$ of Ru was recovered at 338.16 $\mathrm{K}$ after 120 minutes.

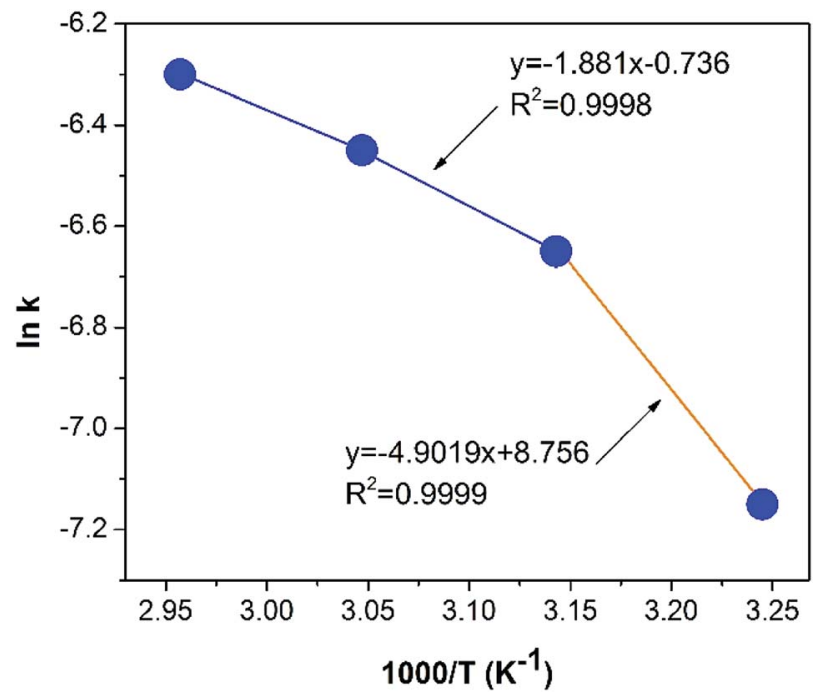

Fig. 3 Kinetics mechanism plots of the Arrhenius plot for the cementation of Ru by Al powder.

\subsection{Characterization of the cemented Ru}

SEM images (Fig. 2a and b) show that the surface cemented Ru on spherical Al powder was roughly aggregated. XRD analysis (Fig. 2c) evidences the $\mathrm{Ru}$ on $\mathrm{Al}$ is the metallic ruthenium (PDF. \# 65-1863), indicating that the cementation was successfully conducted via chemical reduction and deposition of Ru ions from IC foundry's wastewater on to Al surface. Besides, from elemental analysis (Fig. 2d) of EDS, the main constituents of the surface include the cemented $\mathrm{Ru}, \mathrm{Al}_{2} \mathrm{O}_{3}$ and a small amount of phosphorus $\left(0.35 \pm 0.05 \mathrm{mg} \mathrm{g}^{-1}\right)$ and sodium $\left(2.25 \pm 0.02 \mathrm{mg} \mathrm{g}^{-1}\right)$. $\mathrm{Ru} / \mathrm{Al}$ composite has been studied as catalysts. Ru-doped mesoporous Ni-Al oxides catalyst showed high catalytic activity for selective $\mathrm{CO}$ methanation. ${ }^{21}$ Meanwhile, $\mathrm{Ru}$ complexation was functionalized into $\mathrm{Al}$ metal organic framework (MOF) for catalytic oxidation of alcohols. ${ }^{22}$ Currently, Ru recovered on Al powder is being tested as a catalyst for the treatment of textile wastewater and the results will be reported in future.

\subsection{Kinetics of $\mathrm{Ru}$ cementation}

The shrinking core model was employed to characterize the cementation of $\mathrm{Ru}$, in which the gas film diffusion, ash diffusion and chemical reactions during $\mathrm{Ru}$ cementation were considered. For gas film diffusion, the fraction of $\mathrm{Ru}\left(X_{\mathrm{Ru}}\right)$ diffusing into the initial gas film layer of $\mathrm{Al}$ powder at time $t$ $\left(\min ^{-1}\right)$ can be described with a rate constant $k$ as follows: $:^{23,24}$ 
Table 3 Cost-benefit analysis of cementation recovery of Ru

\begin{tabular}{|c|c|c|c|}
\hline Cost/revenue & Used amount & Cost/benefit (USD) & Ref. \\
\hline \multicolumn{4}{|l|}{ Operational cost: } \\
\hline Sodium hydroxide & $0.5 \mathrm{~kg}$ & $\$ 0.145$ & $(\$ 290 \text { per ton })^{34}$ \\
\hline Energy for cementation reaction & $0.035 \mathrm{~kW} \mathrm{~h} \mathrm{~nm}^{-3}$ & $\$ 0.016$ & (Calculated as $\$ 0.16$ per $\mathrm{kW}$ per $\mathrm{h}$ in Taiwan) \\
\hline Energy for drying the sediment & & $\$ 0.032$ & (Calculated as $\$ 0.16$ per $\mathrm{kW}$ per $\mathrm{h}$ in Taiwan) \\
\hline
\end{tabular}

Total operational cost

Revenue:

Revenue from $\mathrm{Ru}$ on aluminum $\quad 0.0023 \mathrm{~kg} \quad \$ 3.105$ powder precipitation

$-\quad \$ 0.180$

( $\$ 1.35$ per $g$ of ruthenium $5 \%$ on aluminum powder, Akshar Noble Pvt Co., India) This study

of integrated circuit (IC) foundry's wastewater

$$
X_{\mathrm{Ru}}=k t
$$

In Ash diffusion, the diffusion of Ru through the ash layer at time $t$ is estimated by: $:^{24,25}$

$$
1-3\left(1-X_{\mathrm{Ru}}\right)^{2 / 3}+2\left(1-X_{\mathrm{Ru}}\right)=k t
$$

Further, the chemical reaction model defined the $\mathrm{Ru}$ removal as a function of time by: ${ }^{23-27}$

$$
1-\left(1-X_{\mathrm{Ru}}\right)^{1 / 3}=k t
$$

The experimental data in (Fig. 1d) fitted by the models using eqn (6)-(8) was plotted in (Fig. 3). Generally, the data is better fitted with the models at lower temperature according to higher values of correlation coefficient $\left(R^{2}\right)$. Cementation of ruthenium is a heterogeneous process which involves the interaction at the solid-liquid interface. Thus, the reactant diffuses through liquid and surface precipitate layers, at which the chemical reaction occurs. This model defines the movement of the reaction zone into the deep unreacted zone. After chemical reaction, the diffuse zone becomes an ash layer which is assumed to be inert. ${ }^{28}$ The results showed that shrinking core model with diffusion through ash layer controlling process was the most suitable model. ${ }^{29}$ Similar conclusion was also reported by other researchers. ${ }^{30}$ As a result, the ash diffusion model better explains the mechanism of $\mathrm{Ru}$ cementation over the $\mathrm{Al}$ powder than the rest of models.

The Arrhenius activation energy of cementation can be resulted from the temperature dependence of the reaction rate constant $(k)$ according to: ${ }^{31,32}$

$$
k=A \exp \left(\frac{-Q}{R T}\right)
$$

where $A$ is the frequency factor; $Q\left(\mathrm{~kJ} \mathrm{~mol}^{-1}\right)$ the reaction activation energy; $R$ the gas constant; and $T$ the absolute temperature. The values of $\ln k$ from the ash diffusion mechanism against reciprocal of temperature in (Fig. 3) indicates two slopes in the different temperature ranges of 308.16-318.16 $\mathrm{K}$ and
318.16-338.16 K, which yield activation energies of $40.75 \mathrm{~kJ} \mathrm{~mol}^{-1}$ and $15.65 \mathrm{~kJ} \mathrm{~mol}^{-1}$, respectively. Such a shift in the activation energy is probably due to the change in the reaction mechanisms. In other words, two consecutive processes may control the reaction steps; at low temperature, the diffusion-controlled process (which is strongly dependent on temperature) predominates, while at high temperature the chemically controlled process becomes significant (which is slightly dependent on temperature). Therefore, the reactioncontrolling step between 308.16 and $318.16 \mathrm{~K}$ is the ash diffusion highly sensitive to temperature. At 318.16-338.16 K, consequently, the activation energy of chemical reaction is $40.75 \mathrm{~kJ} \mathrm{~mol}^{-1}$. On the other hand, the profit gained per volume of IC foundry's wastewater was presumed to linearly rise with increasing the chemical concentration (Table 3). A $0.1 \mathrm{~m}^{3}$ wastewater of IC foundry typically contains $0.0023 \mathrm{~kg} \mathrm{Ru} .0 .5 \mathrm{~kg}$ $\mathrm{NaOH}$ and $1.2 \mathrm{~kg} \mathrm{Al}$ powder are required to recover $98.5 \% \mathrm{Ru}$ from the wastewater, resulted in a profit of $\$ 0.180$ per $0.1 \mathrm{~m}^{3}$ wastewater.

\section{Conclusions}

This study recovered Ru from the wastewater of IC foundry by cementation using metallic aluminum ( $\mathrm{Al}$ ) powder as the sacrificial agent. $\mathrm{Ru}$ ion was efficiently reduced as metal and coagulated with the derived aluminum hydroxide flocs. Experimental parameters included the particle size of $\mathrm{Al}$, molar ratio of $\mathrm{Al}$ to $\mathrm{Ru}$, initial $\mathrm{Ru}$ concentration and operation temperature. The recovery rate attained 99\% under the conditions: particle size $\mathrm{Al}$ powder $=88-128 \mu \mathrm{m}, \mathrm{Al} / \mathrm{Ru}$ molar ratio $=2.0$, initial $\mathrm{Ru}$ $=200 \mathrm{mg} \mathrm{L}^{-1}$, temperature $=338.16 \mathrm{~K}$, reaction time $=$ $120 \mathrm{~min}$, stirring speed $=150 \mathrm{rpm}$. Kinetic modelling suggested that the diffusion of $\mathrm{Ru}$ through the ash layer of $\mathrm{Al}$ powder controlled the reaction rate with an activation energy of $40.75 \mathrm{~kJ} \mathrm{~mol}^{-1}$. A brief cost analysis demonstrated that the cementation of $\mathrm{Ru}$ yielded a profit of $\$ 0.180$ per $0.1 \mathrm{~m}^{3}$-wastewater. The method was found to be robust when applied in an industrial scale treatment facility. 


\section{Conflicts of interest}

There are no conflicts to declare.

\section{Acknowledgements}

The authors greatly acknowledge the help of Mr Nicolaus Nezha Nunez Mahasti for experimental setup and technical input. We would like to thank Mr I.-Chin Sung, Mr Tsung-Yen Wu and Ms Michelle Chu for their help in SEM, EDS and XRD analyses.

\section{References}

1 A. M. Weisberg, Met. Finish., 1999, 97, 297.

2 J. Emsley, “Ruthenium”. Nature's Building Blocks: An A-Z Guide to the Elements, UK Oxford University Press, 2003, pp. 368370.

3 F. Cardarelli, Mater. Des., 2008, 237.

4 M. S. Varney, Ocean Sci. Technol., 2000, 322.

5 A. D. Richards and A. Rodger, Chem. Soc. Rev., 2007, 36, 471483.

6 A. Fürstner, Angew. Chem., Int. Ed., 2000, 39, 3012-3043.

7 T. O. R. Noyori and M. Kitamura, J. Am. Chem. Soc., 1987, 109, 5856-5858.

8 M. A. Hayat, Language of science, Springer, US, 1993.

9 P. Swain, C. Mallika, R. Srinivasan, U. K. Mudali and R. Natarajan, J. Radioanal. Nucl. Chem., 2013, 298, 781-796.

10 K. Naito, T. Matsui, H. Nakahira, M. Kitagawa and H. Okada, J. Nucl. Mater., 1991, 184, 30-38.

11 K. Singh, N. L. Sonar, T. P. Valsala, Y. Kulkarni, T. Vincent and A. Kumar, Desalin. Water Treat., 2014, 52, 514-525.

12 M. Blicharska, B. Bartoś, S. Krajewski and A. Bilewicz, J. Radioanal. Nucl. Chem., 2013, 298, 1713-1716.

13 S. Aktas, Hydrometallurgy, 2011, 106, 71-75.

14 F. L. Bernardis, R. A. Grant and D. C. Sherrington, React. Funct. Polym., 2005, 65, 205-217.

15 F. Crundwell, M. Moats, V. Ramachandran, T. Robinson and W. G. Davenport, Extractive metallurgy of nickel, cobalt and platinum group metals, Elsevier, 2011.
16 K. Lillkung and J. Aromaa, Dissolution of Platinum, Palladium and Rhodium in $250 \mathrm{~g} / \mathrm{l} \mathrm{NaCl} \mathrm{Solution/TT} \mathrm{Chen} \mathrm{Honorary}$ Symposium on Hydrometallurgy, Electrometallurgy and Materials Characterization, 2012, pp. 359-369.

17 F. Farahmand, D. Moradkhani, M. Sadegh Safarzadeh and F. Rashchi, Hydrometallurgy, 2009, 98, 81-85.

18 I. S. Kwak, S. W. Won, Y. S. Chung and Y.-S. Yun, Bioresour. Technol., 2013, 128, 30-35.

19 H. Ohta, K. Akiba and Y. Onodera, J. Nucl. Sci. Technol., 2002, 39, 655-660.

20 M. H. M. Serdar Aktas, K. Aksu and B. Aksoy, Trans. Indian Inst. Met., 2018, 71, 697-703.

21 A. Chen, T. Miyao, K. Higashiyama, H. Yamashita and M. Watanabe, Angew. Chem., Int. Ed., 2010, 49, 9895-9898.

22 F. Carson, S. Agrawal, M. Gustafsson, A. Bartoszewicz, F. Moraga, X. Zou and B. Martín-Matute, Chem.-Eur. J., 2012, 18, 15337-15344.

23 P. K. Gbor and C. Q. Jia, Chem. Eng. Sci., 2004, 59, 1979-1987. 24 S. Noorman, F. Gallucci, M. van Sint Annaland and J. A. M. Kuipers, Chem. Eng. J., 2011, 167, 297-307.

25 O. Levenspiel, Ind. Eng. Chem. Res., 1999, 38, 4140-4143.

26 V. Buscaglia and C. Milanese, Diffusion-Controlled SolidState Reactions of Spherical Particles, A General Model for Multiphase Binary Systems, J. Phys. Chem. B, 2005, 1847518482.

27 M. R. Talaghat and E. Zangooei, Journal of Chemical and Petroleum Engineering, 2017, 51, 9-19.

28 O. Levenspiel, Ind. Eng. Chem. Res., 1999, 38, 4140-4143.

29 W. Astuti, T. Hirajima, K. Sasaki and N. Okibe, Trans. Soc. Min., Metall., Explor., 2015, 32, 176-185.

30 V. Safari, G. Arzpeyma, F. Rashchi and N. Mostoufi, Int. J. Miner. Process., 2009, 93, 79-83.

31 O. Levenspiel, Ind. Eng. Chem. Res., 1999, 38, 4140-4143.

32 L. A. Wall and J. H. Flynn, Polym. Lett., 1966, 4, 323-328.

33 G. Colica, S. Caparrotta and R. De Philippis, Appl. Microbiol. Biotechnol., 2012, 95, 381-387.

34 H. Huang, D. Xiao, J. Liu, L. Hou and L. Ding, Sci. Rep., 2015, 5, 10183. 